\title{
Effects of dietary energy density and digestible protein:energy ratio on de novo lipid synthesis from dietary protein in gilthead sea bream (Sparus aurata) quantified with stable isotopes
}

\author{
Kim S. Ekmann ${ }^{1 *}$, Johanne Dalsgaard ${ }^{1}$, Jørgen Holm², Patrick J. Campbell ${ }^{3}$ and Peter V. Skov ${ }^{1}$ \\ ${ }^{1}$ Technical University of Denmark, DTU Aqua, Section for Aquaculture, The North Sea Research Centre, \\ PO Box 101, DK-9850 Hirtshals, Denmark \\ ${ }^{2}$ BioMar A/S, Mylius Erichsensvej 35, DK-7330 Brande, Denmark \\ ${ }^{3}$ BioMar Limited, North Shore Road, Grangemouth Docks, Grangemouth FK3 8UL, Scotland, UK \\ (Submitted 19 October 2012 - Final revision received 8 March 2013 - Accepted 22 March 2013 - First published online 1 May 2013)
}

\section{Abstract}

The effects of varying dietary digestible protein (DP) and digestible energy (DE) content on performance, nutrient retention efficiency and the de novo lipogenesis of DP origin were examined in triplicate groups of gilthead sea bream (Sparus aurata), fed nine extruded experimental diets. In order to trace the metabolic fate of dietary protein, $1.8 \%$ fishmeal was replaced with isotope-labelled whole protein $\left(>98 \%{ }^{13} \mathrm{C}\right.$ ). The experiment was divided into a growth period lasting $89 \mathrm{~d}$, growing fish from approximately 140 to $350 \mathrm{~g}$, followed by a $3 \mathrm{~d}$ period feeding isotope-enriched diets. Isotope ratio MS was applied to quantify the ${ }^{13} \mathrm{C}$ enrichment of whole-body lipid from dietary DP. Between 18.6 and $22.4 \%$ of the carbon derived from protein was recovered in the lipid fraction of the fish, and between 21.6 and $30.3 \%$ of the total lipid deposited could be attributed to dietary protein. DP retention was significantly improved by reductions in dietary DP:DE ratio, while the opposite was true for apparent digestible lipid retention. Both overall DE retention and whole-body proximate composition of whole fish were largely unaffected by dietary treatments, while feed conversion ratios were significantly improved with increasing dietary energy density. The present study suggests that gilthead sea bream efficiently utilises dietary nutrients over a wide range of DP:DE ratios and energy densities. In addition, they appear to endeavour a certain body energy status rather than maximising growth, which in the present trial was apparent from inherently high de novo lipogenesis originating from DP.

Key words: Gilthead sea bream: Stable isotopes: Protein-to-energy ratio: Lipogenesis

One of the biggest expenses in modern aquaculture is feed cost. Thus, maximised feed utilisation per unit cost is of paramount importance in maintaining an economically viable aquaculture enterprise. In commercial fish feed production, the main concern is the quality, quantity and ratio between nutrients supplied through the raw materials used, and the cost of combining these to fit the nutritional requirements of a specific farmed species at a specific life stage. These nutrient requirements, however, are not absolute. Rather, they should be present in the correct proportion to each other as pointed out by Wilson ${ }^{(1)}$ with respect to protein requirements. According to him, the protein requirement of an animal comprises a well-balanced mixture of essential and non-essential amino acids, where protein digestibility, amino acid profile and energy concentration of the diet are also considered.
Consequently, two of the most commonly used diet optimisation 'tools' in aquaculture comprise amino acid optimisation ('ideal protein concept') $^{(2-4)}$, and optimisation of the ratio between digestible protein (DP) and digestible energy $(\mathrm{DE})^{(5-9)}$. The optimal DP:DE ratio refers to the minimum amount of DP required for optimising a certain production trait, such as growth, feed conversion or protein retention at a given DE density. Diets containing DP in excess of requirements will lead to excessive protein deamination, which in turn increases the discharge of nitrogenous compounds into the environment ${ }^{(10,11)}$. Additionally, protein is the most costly macronutrient in aquaculture diets. Thus, there is an economic incentive not to include this nutrient in excess of requirements.

Historically, gilthead sea bream (Sparus aurata) has been perceived to have a high dietary protein requirement, and

Abbreviations: aDLR, apparent digestible lipid retention; ADC, apparent nutrient digestibility coefficient; APE, atom per cent excess; DE, digestible energy; DER, digestible energy retention; DP, digestible protein; DP:DE ratio, digestible protein:digestible energy ratio; DPR, digestible protein retention; FCR, feed conversion ratio; IAA, indispensable amino acid; LDPO, lipid deposition of protein origin; LE/ME/HE, low/medium/high digestible energy; LP/MP/HP, low/ medium/high digestible protein; RPCL, recovery of protein-derived carbon in fish lipid; SGR, specific growth rate. 
relatively poor protein utilisation and feed conversion compared with other aquacultured species such as salmonids. This is also reflected in the reported optimal DP:DE ratios for this species ${ }^{(12,13)}$, which are considerably higher than for farmed salmonids at the same life stage ${ }^{(14-16)}$. Irrespective of species, practically all DP/DE studies reported so far have focused on optimising protein retention. In practice, this is typically done by reducing the dietary DP/DE level, by substituting DE supplied from DP with DE supplied from nonprotein DE sources such as fat ${ }^{(17-20)}$ or carbohydrates ${ }^{(18,21-25)}$. Only a few studies have commented on the metabolic fate of non-retained (deaminated) protein in this respect ${ }^{(26,27)}$.

Recent studies have indicated that a substantial part of the deaminated amino acids in blackspot seabream (Pagellus bogaraveo) were converted into fatty acids de novo ${ }^{(27)}$. This was expressed by increased hepatic lipogenic enzyme activities and the increased hepatic content of palmitic and stearic acids, which are generally recognised to be the main products of de novo lipogenesis ${ }^{(28)}$. Additionally, studies by Enes ${ }^{(29,30)}$ have shown a positive correlation between dietary protein level and lipogenic enzyme activity both in gilthead sea bream and European seabass (Dicentrarchus labrax), indicating that protein may contribute to lipid biosynthesis in this species. However, since deaminated protein can precede both gluconeogenesis, lipogenesis and complete oxidation for energy purposes, it is hard to quantitatively conclude on the fate of deaminated protein.

The main purpose of the present study was to quantify the amount of dietary protein endogenously converted to body lipid de novo in gilthead sea bream using nine diets enriched with stable isotopes that differed in DP/DE levels and energy density. Additionally, macronutrient retention efficiencies, growth and feed performance parameters were determined. To achieve this, a study comprising two trial periods was conducted. First, an $89 \mathrm{~d}$ growth period was carried out feeding gilthead sea bream nine diets differing in DP and DE content. Based on this specific growth rate (SGR), feed conversion ratio (FCR), nutrient digestibility coefficients (ADC), DP retention (DPR), DE retention (DER) and apparent lipid retention (aDLR) were determined. Second, and immediately following the growth period, fish were fed their respective diets for three more days, only now diets were added trace amounts of ${ }^{13} \mathrm{C}$-labelled protein isolate. This was done to determine the extent to which dietary protein was converted into body lipid endogenously, and to determine how much this lipid biosynthesis contributed to the overall lipid deposition in the fish. As deposited lipid could originate from both dietary and endogenous sources (de novo lipogenesis), digestible lipid retention efficiencies are henceforth referred to as 'apparent'.

\section{Materials and methods}

\section{Culture conditions and fish}

Gilthead sea bream with an average individual weight of approximately $120 \mathrm{~g}$ were obtained from a commercial fish farm (Ferme Marine de Douhet). They were subsequently stocked into a recirculated aquaculture system comprising twenty-seven fibreglass tanks with a volume of 800 litres, each at a stocking density of twenty fish/tank (BioMar research facility; The North Sea Research Centre). The tanks were fitted with a central bottom drain designed to quickly and efficiently remove faeces and uneaten feed pellets from the water by means of externally mounted swirl separators. The trial facility was supplied with filtered North Sea water with a salinity of $34 \mathrm{~g} / \mathrm{l}$, and the temperature was kept at $24^{\circ} \mathrm{C}$ throughout the trials. Water quality was monitored daily, maintaining $\mathrm{O}_{2}$ saturation between 80 and $100 \%, \mathrm{NH}^{4+}$ below $1.0 \mathrm{mg} / \mathrm{l}, \mathrm{NO}^{2-}$ below $1.0 \mathrm{mg} / 1$ and $\mathrm{NO}^{3-}$ below $100 \mathrm{mg} / \mathrm{l}$. $\mathrm{pH}$ was adjusted to $7 \cdot 0$ using sodium bicarbonate when necessary. The tanks were supplied with system water at a flow rate of 1200 litres/tank per h. A $14 \mathrm{~h}$ light-10 h dark photoperiod was maintained throughout the trials. All fish were acclimatised to the facility for 2 weeks during which they were fed a commercial diet (BioMar EFICO YM 664; DP/DE level $21.7 \mathrm{~g} / \mathrm{MJ}$ ) according to a commercial feeding table value ( $1.5 \%$ of the biomass per $\mathrm{d}$ ).

\section{Experimental diets}

A total of nine experimental diets were prepared using Allix ${ }^{2}$ feed formulation software (A-systems S.A.; Table 1). The main dietary ingredients were fishmeal, fish oil, wheat and field peas, and the diets were formulated to contain three DP levels $(330,360$ or $380 \mathrm{~g} / \mathrm{kg}$ ) and three DE levels (20, 21 or $22 \mathrm{MJ} / \mathrm{kg}$ ) in a $3 \times 3$ factorial design. The diets were named according to their DP and DE content (LP, MP or HP for low, medium or high DP content, respectively, and LE, ME or HE for low, medium or high DE content, respectively). For example, the diet LPLE refers to the low DP:low DE diet (expected to contain $330 \mathrm{~g} / \mathrm{kg}$ DP and $20 \mathrm{MJ} / \mathrm{kg} \mathrm{DE}$ ). The following two versions of each diet were made: one where approximately $1.8 \%$ of the dietary fishmeal was substituted with a ${ }^{13} \mathrm{C}$-labelled $\left(97-98 \%{ }^{13} \mathrm{C}\right)$ Spirulina protein isolate (Cambridge Isotope Laboratories, Inc.), and one unlabelled version. The Spirulina protein isolate was chosen as an isotope marker due to its close resemblance to fishmeal regarding the amino acid profile and the lack of non-protein macronutrients that could potentially adversely affect the enrichment data. The diets were supplemented with a vitamin and mineral premix, as well as monocalcium phosphate. Guar gum was added $(5 \mathrm{~g} / \mathrm{kg})$ to enhance pellet stability and accurately quantify feed waste, and yttrium oxide $\left(\mathrm{Y}_{2} \mathrm{O}_{3}\right)$ was added $(0.3 \mathrm{~g} / \mathrm{kg})$ as an inert marker enabling indirect measurements of nutrient and stable isotope digestibility. The diets were prepared at the BioMar TechCenter using a twin-screw extruder (Clextral BC-45; Firminy) to produce $4.5 \mathrm{~mm}$ pellets. Following extrusion, the diets were dried in a six-level Geelen counterflow continuous dryer (Geelen Counterflow), vacuum coated with fish oil and cooled.

\section{Experimental procedures}

The study comprised two trial periods: (1) an $89 \mathrm{~d}$ growth period (growing fish from approximately 140 to $340 \mathrm{~g}$ ) feeding 
Table 1. Diet formulation, chemical and isotope composition of the experimental diets

(Mean values and standard deviations; percentages)

\begin{tabular}{|c|c|c|c|c|c|c|c|c|c|}
\hline Diets... & LPLE & LPME & LPHE & MPLE & MPME & MPHE & HPLE & HPME & HPHE \\
\hline \multicolumn{10}{|l|}{ Ingredients $(\mathrm{g} / \mathrm{kg})^{\star}$} \\
\hline Fishmealt & $442(434)$ & $448(440)$ & $453(445)$ & $498(489)$ & $504(495)$ & $509(500)$ & $554(544)$ & $559(549)$ & $565(555)$ \\
\hline Fish oil & 180 & 218 & 257 & 163 & 202 & 240 & 146 & 185 & 223 \\
\hline Wheat & 207 & 161 & 115 & 154 & 108 & 61 & 101 & 55 & 8 \\
\hline Field peas & 147 & 149 & 151 & 166 & 168 & 170 & 185 & 186 & 188 \\
\hline Guar gum & 5 & 5 & 5 & 5 & 5 & 5 & 5 & 5 & 5 \\
\hline Vitamin and mineral premix & 3 & 3 & 3 & 3 & 3 & 3 & 3 & 3 & 3 \\
\hline Monocalcium phosphate & 16 & 16 & 16 & 11 & 11 & 11 & 7 & 7 & 7 \\
\hline $\mathrm{Y}_{2} \mathrm{O}_{3}$ & 0.3 & 0.3 & 0.3 & 0.3 & 0.3 & 0.3 & 0.3 & 0.3 & 0.3 \\
\hline${ }^{13} \mathrm{C}$ protein isolate $\dagger$ & (8) & (8) & (8) & (9) & (9) & (9) & (10) & (10) & (10) \\
\hline \multicolumn{10}{|l|}{ Proximate composition $(\mathrm{g} / \mathrm{kg})$} \\
\hline DM & 930 & 921 & 920 & 915 & 909 & 922 & 917 & 918 & 920 \\
\hline Crude protein & 385 & 372 & 375 & 409 & 404 & 404 & 453 & 443 & 444 \\
\hline Crude fat & 230 & 274 & 308 & 219 & 256 & 304 & 210 & 254 & 283 \\
\hline Starch & 193 & 192 & 126 & 168 & 152 & 102 & 133 & 106 & 84 \\
\hline Ash & 74 & 72 & 72 & 73 & 74 & 73 & 77 & 76 & 77 \\
\hline \multicolumn{10}{|l|}{ Energy calculations } \\
\hline Gross energy $(\mathrm{MJ} / \mathrm{kg}) \ddagger$ & $22 \cdot 4$ & $23 \cdot 1$ & 23.9 & $22 \cdot 0$ & $22 \cdot 7$ & $24 \cdot 0$ & $22 \cdot 1$ & $23 \cdot 0$ & 23.7 \\
\hline $\mathrm{DE}(\mathrm{MJ} / \mathrm{kg}) \S$ & 19.9 & $21 \cdot 2$ & $21 \cdot 4$ & $19 \cdot 6$ & 20.7 & $21 \cdot 6$ & $19 \cdot 7$ & $20 \cdot 6$ & 21.3 \\
\hline$D P(g / k g) \|$ & 344 & 331 & 334 & 363 & 363 & 361 & 405 & 395 & 395 \\
\hline DP:DE ratio (g/MJ) & $17 \cdot 3$ & $15 \cdot 6$ & $15 \cdot 6$ & 18.5 & 17.5 & $16 \cdot 7$ & $20 \cdot 6$ & $19 \cdot 1$ & 18.5 \\
\hline \multicolumn{10}{|l|}{ Carbon content of the diets (\%) } \\
\hline \multicolumn{10}{|l|}{ Non-enriched diets } \\
\hline Mean & $47 \cdot 74$ & 49.89 & $51 \cdot 25$ & 48.69 & 48.44 & $50 \cdot 04$ & $47 \cdot 17$ & $49 \cdot 19$ & $50 \cdot 11$ \\
\hline \multirow{2}{*}{\multicolumn{10}{|c|}{${ }^{13} \mathrm{C}$-enriched diets }} \\
\hline & & & & & & & & & \\
\hline Mean & $46 \cdot 19$ & $50 \cdot 20$ & 51.08 & $46 \cdot 50$ & $50 \cdot 38$ & $50 \cdot 74$ & $48 \cdot 70$ & 49.50 & $49 \cdot 61$ \\
\hline $\mathrm{SD}$ & 1.01 & 1.29 & 1.36 & 0.63 & 1.20 & 1.64 & 0.74 & $1 \cdot 12$ & 0.82 \\
\hline \multicolumn{10}{|l|}{$\delta^{13} \mathrm{C}$ values of the diets (\%) } \\
\hline \multicolumn{10}{|l|}{ Non-enriched diets } \\
\hline Mean & -22.48 & -22.40 & $-22 \cdot 23$ & $-22 \cdot 12$ & -21.44 & -21.52 & $-21 \cdot 25$ & -21.59 & $-21 \cdot 81$ \\
\hline SD & 0.17 & 0.06 & 0.09 & 0.13 & 0.27 & 0.71 & 0.25 & 0.30 & 0.12 \\
\hline \multicolumn{10}{|l|}{${ }^{13} \mathrm{C}$-enriched diets } \\
\hline Mean & 594.54 & 596.93 & 593.91 & 661.68 & 663.74 & 663.23 & $753 \cdot 28$ & 754.48 & 753.25 \\
\hline SD & $17 \cdot 12$ & $15 \cdot 01$ & $16 \cdot 27$ & $18 \cdot 90$ & $17 \cdot 30$ & 26.67 & $25 \cdot 18$ & 8.53 & 34.83 \\
\hline \multicolumn{10}{|l|}{${ }^{13} \mathrm{C}$ APE of the diets (\%) } \\
\hline${ }^{13} \mathrm{C}$-enriched diets & 0.6738 & 0.6762 & 0.6728 & 0.7461 & 0.7476 & 0.7471 & 0.8443 & 0.8459 & 0.8448 \\
\hline \multicolumn{10}{|l|}{${ }^{13} \mathrm{C}$ enrichment of protein $\mathrm{C}(\%)$} \\
\hline${ }^{13} \mathrm{C}$-enriched diets & 1.718 & 1.943 & 1.950 & 1.805 & 1.982 & 1.998 & 1.931 & $2 \cdot 010$ & $2 \cdot 010$ \\
\hline
\end{tabular}

LPLE, low digestible protein (DP):low digestible energy (DE) diet; LPME, low DP:medium DE diet; LPHE, low DP:high DE diet; MPLE, medium DP:Iow DE diet; MPME, medium DP:medium DE diet; MPHE, medium DP:high DE diet; HPLE, high DP:Iow DE diet; HPME, high DP:medium DE diet; HPHE, high DP:high DE diet; APE, atom per cent excess.

*Fishmeal: TripleNine Fish Protein; Fish oil: South American (Peru); Guar gum: HV200; LCH A/S; ${ }^{13} \mathrm{C}$-labelled protein isolate: Cambridge Isotope Laboratories, Inc., algal crude protein fraction isolated from Spirulina algae (U- ${ }^{13} \mathrm{C}$, 97-98\%), lot no. BP-733, catalogue no. CLM-3348-0; Cambridge Isotope Laboratories, Inc.; vitamin and mineral mix is estimated to meet the requirements according to the US National Research Council recommendations ${ }^{(49)}$. † Each of the nine diets were produced in a ${ }^{13} \mathrm{C}$-enriched version (where ${ }^{13} \mathrm{C}$-labelled protein isolate replaced approximately $1.8 \%$ of the con-kix fishmeal; shown in brackets) and a non-enriched version in order to determine ${ }^{13} \mathrm{C}$

$\neq$ Gross energy (MJ/kg) was calculated as the sum of the dietary content of protein, lipid and $\mathrm{N}$-free extract (NFE), multiplied by their respective energetic values upon complete oxidation ${ }^{(50)}$ : Gross energy $=\left(P_{\text {diet }} \times 23.66\right)$ $+\left(L_{\text {diet }} \times 39.57\right)+($ NFE diet $\times 17.17)$, where $P_{\text {diet }}, L_{\text {diet }}$ and NFE diet refer to the dietary protein, lipid and NFE content (\%), respectively. NFE was calculated as the sum of dietary protein, lipid, ash and water deducted from $100 \%$ (by difference).

$\S$ The $D E(M J / k g)$ content was calculated as the dietary gross energy, but with the apparent nutrient digestibility coefficients $(A D C)$ of each nutrient multiplied into their respective terms: $D E=\left(P_{\text {diet }} \times 23.66 \times A D C_{\text {protein }}\right)$ $+\left(L_{\text {diet }} \times 39.57 \times \mathrm{ADC}_{\text {lipid }}\right)+\left(S_{\text {diet }} \times 17.17 \times \mathrm{ADC}_{\text {starch }}\right)$, where $S_{\text {diet }}$ is the dietary starch content, and $A \mathrm{AC}_{\text {protein, }}, \mathrm{ADC}_{\text {lipid }}$ and $\mathrm{ADC}$ starch are the $\mathrm{ADC}$ of protein, lipid and starch, respectively.

$\| \mathrm{DP}(\mathrm{g} / \mathrm{kg})=$ dietary crude protein content $\times A D C_{\text {protein. }}$. 
each of the nine unlabelled diets to three replicate tanks (i.e. twenty-seven tanks in all), and concluded by a faeces stripping procedure to determine the ADC of macronutrients, and subsequently (2) a $3 \mathrm{~d}$ enrichment period feeding the ${ }^{13} \mathrm{C}$-enriched versions of the experimental diets to determine the proportion of dietary protein converted into body lipid de novo, and to determine the ADC of the two stable carbon isotopes $\left({ }^{12} \mathrm{C}\right.$ and $\left.{ }^{13} \mathrm{C}\right)$. All procedures were carried out in accordance with the EC directive 86/609/EEC for animal experiments ${ }^{(31)}$.

Growth period. At start-up, five randomly chosen fish were removed from each of the twenty-seven tanks and euthanised using $250 \mathrm{mg} / \mathrm{l}$ of tricaine methanesulfonate (MS-222). The $5 \times 27$ fish were subsequently pooled and stored at $-20^{\circ} \mathrm{C}$ until analysis, constituting the initial fish sample. The remaining fifteen fish in each tank were weighed, and the nine experimental diets were fed to triplicate tanks for $89 \mathrm{~d}$. The fish were fed a ration recalculated from a commercial feeding table value for gilthead sea bream, allowing a restrictive isoDE feeding regimen based on the expected DE content of the respective experimental diets. Any uneaten feed was collected daily and subtracted in the calculations of feed intake. Fish were fed continuously from 08.00 to 14.00 hours using automatic belt feeders. On day 89, the final meal was administered $18 \mathrm{~h}$ before faeces stripping, where the fish were anaesthetised using MS-222 (50 mg/l), and a gentle bilateral pressure was applied to the hindgut in order to provoke defecation. Faeces obtained from the fish within each tank were pooled and immediately frozen at $20^{\circ} \mathrm{C}$. At $24 \mathrm{~h}$ after the stripping procedure, fish were bulk weighed, and seven fish from each tank were removed, euthanised using MS-222 (250 mg/l) and subsequently stored at $20^{\circ} \mathrm{C}$ for chemical and isotopic analysis.

${ }^{13} \mathrm{C}$ enrichment period. Following the stripping procedure of the growth trial, the eight remaining fish in each tank were fed their respective nine experimental diets for three more days, only now in the ${ }^{13} \mathrm{C}$ protein-enriched version at a feeding rate calculated as described in the 'Growth period' section. Uneaten feed was collected daily and subtracted in the calculations of feed intake. At $18 \mathrm{~h}$ after the final meal, fish fed the diet MPME (three tanks in all) were stripped for faecal matter according to the method described in the 'Growth period' section. This was done in order to determine the ADC of the two stable carbon isotopes $\left({ }^{12} \mathrm{C}\right.$ and $\left.{ }^{13} \mathrm{C}\right)$, assuming that they were representative of all the experimental diets. Fish were starved for $48 \mathrm{~h}$ after the final meal, and subsequently euthanised using MS-222 (250 mg/l), weighed and stored at $20^{\circ} \mathrm{C}$ for chemical and isotopic analysis.

\section{Sample preparation and chemical and isotopic analysis}

Feed samples. Feed samples were homogenised before analysis using a Krups Speedy Pro homogeniser. Crude protein was determined according to the $\mathrm{ISO}^{(32)}$, crude fat according to Bligh \& Dyer ${ }^{(33)}$, and DM and ash according to Kolar ${ }^{(34)}$. Yttrium was determined according to the ISO $^{(35)}$ and Danish Standards ${ }^{(36)}$. Starch analyses were carried out according to the method by Bach Knudsen ${ }^{(37)}$, while amino acids were determined according to the $\mathrm{EC}^{(38)}$ and $\mathrm{ISO}^{(39)}$. Aliquots of the homogenised feed samples were lyophilised and finely ground using a mortar and pestle before the determination of ${ }^{13} \mathrm{C}$ isotope enrichment and elemental carbon (see the 'Isotopic analysis' section).

Faecal samples. Faecal samples were freeze-dried before analysis using a Christ Beta 2-16 freeze dryer (Martin Christ Gefriertrocknungsanlagen $\mathrm{GmbH}$ ). Faecal protein was determined by elemental analysis according to the method described in the 'Isotopic analysis' section, assuming that protein equals $6 \cdot 25 \times \mathrm{N}$. Faecal lipid was determined according to Bligh \& Dyer ${ }^{(33)}$. Faecal starch was determined using a BioVision Starch assay kit (catalogue no. K647-100, Tecan GENios microplate reader (Austria) fitted with a $570 \mathrm{~nm}$ colorimetric filter), and yttrium was determined according to the ISO ${ }^{(35)}$ and Danish Standards ${ }^{(36)}$. Aliquots of the faecal samples were lyophilised and finely ground using a mortar and pestle before the determination of ${ }^{13} \mathrm{C}$ isotope enrichment, and elemental $\mathrm{C}$ and $\mathrm{N}$ (see the 'Isotopic analysis' section).

Fish samples. Fish sampled initially (one pooled sample), at the end of the growth trial (twenty-seven samples), and after the ${ }^{13} \mathrm{C}$ enrichment trial (twenty-seven samples) were homogenised in a two-step procedure before chemical and/ or isotopic analysis. Frozen fish samples were homogenised for $60 \mathrm{~s}$ using a Tecator 1094 homogeniser (Tecator AB), and an aliquot of each sample was further homogenised for $30 \mathrm{~s}$ using a Büchi Mixer B-400 (BÜCHI Labortechnik AG). All sample aliquots were subjected to crude protein, crude lipid, DM and ash analyses, using the same methodology as described for feed (see the 'Feed samples' section). Samples obtained at the end of the growth trial and at the end of the isotope enrichment trial were additionally subjected to stable carbon isotope analysis of their respective lipid fractions. Lipid samples for isotopic analysis were obtained during the lipid extraction process of the Bligh \& Dyer ${ }^{(33)}$ procedure.

Isotopic analysis. Feed (enriched and unenriched) and isolated whole-body lipid samples were all subjected to stable isotope $\left(\delta^{13} \mathrm{C}\right)$ and elemental carbon analysis, while faecal samples were additionally subjected to elemental $\mathrm{N}$ analysis. Before isotopic analysis, aliquots of all samples were packed and weighed into tin capsules (standard weight pressed tin capsules $5 \times 3.5 \mathrm{~mm}$, catalogue no. D1002; Elemental Microanalysis Limited) using an analytical microbalance (Mettler Toledo MT5; Mettler). All stable isotope enrichment, elemental $\mathrm{C}$ and $\mathrm{N}$ analyses were carried out using a Thermoquest EA1110 CHNS-O elemental analyser coupled to a Thermo Scientific Delta V advantage isotope ratio mass spectrometer via a Thermo Scientific ConFlo IV module.

\section{Calculations}

Stable ${ }^{13} \mathrm{C}$ isotope enrichment $\left(\delta^{13} \mathrm{C}, \% 0\right)$ of samples was calculated as:

$$
\delta^{13} \mathrm{C}=\left(\left(R_{\text {sample }}-R_{\text {standard }}\right) /\left(R_{\text {standard }}\right)\right) \times 1000,
$$

where $R_{\text {sample }}$ is the ${ }^{13} \mathrm{C}:{ }^{12} \mathrm{C}$ ratio of the sample, and $R_{\text {standard }}$ is the ${ }^{13} \mathrm{C}:{ }^{12} \mathrm{C}$ ratio of the reference standard calibrated against the international standard V-PDB (Pee Dee Belemnite). The ${ }^{13} \mathrm{C}$ atom per cent excess (APE, \%) of the samples was 
determined as the difference between the atom percentage $\left({ }^{13} \mathrm{C}\right.$ atm $\left.\%\right)$ of the enriched sample and the unenriched sample ('blank'), according to:

$$
\operatorname{APE}\left({ }^{13} \mathrm{C}\right)={ }^{13} \mathrm{C} \text { atm } \%_{\text {sample }}-{ }^{13} \mathrm{C} \text { atm } \%_{\text {blank }} .
$$

Atomic percentages were calculated as:

$$
\begin{aligned}
{ }^{13} \mathrm{Catm} \%= & \left(100 \times \mathrm{AR} \times\left(\left(\delta^{13} \mathrm{C} / 1000\right)+1\right)\right) /(1+\mathrm{AR} \\
& \left.\times\left(\left(\delta^{13} \mathrm{C} / 1000\right)+1\right)\right),
\end{aligned}
$$

where $\mathrm{AR}$ is the absolute ${ }^{13} \mathrm{C}:{ }^{12} \mathrm{C}$ ratio of V-PDB (0.0112372) as given by Craig $^{(40)}$.

Lipid deposition of protein origin (LDPO, \%) expressed as a fraction of total lipid deposited was calculated according to:

$$
\begin{aligned}
\mathrm{LDPO}= & \left(\left(\mathrm{BM}_{\mathrm{end}} \times \mathrm{BL}_{\mathrm{end}} \times C_{\mathrm{wbl}} \times{ }^{13} \mathrm{CAPE}_{\mathrm{wbl}}\right) / \mathrm{PE}_{\mathrm{diet}}\right) /\left(\mathrm{FI}_{\mathrm{enr}}\right. \\
& \left.\times \mathrm{DL} \times \mathrm{ADC}_{\text {lipid }} \times \mathrm{aDLR} \times C_{\mathrm{wbl}}\right),
\end{aligned}
$$

where $\mathrm{BM}_{\text {end }}$ is the end biomass (in $\mathrm{g}$ ); $\mathrm{BL}_{\mathrm{end}}$ is the end body lipid content (in \%); $C_{\mathrm{wbl}}$ is the end whole-body lipid carbon content (in \%); ${ }^{13} \mathrm{C} \mathrm{APE}_{\mathrm{wbl}}$ is the ${ }^{13} \mathrm{C}$ APE in the whole-body lipid fraction of the fish (in \%) at the end of the $3 \mathrm{~d}$ enrichment period; $\mathrm{PE}_{\mathrm{diet}}$ is the ${ }^{13} \mathrm{C}$ enrichment of dietary protein (in \%); $\mathrm{FI}_{\text {enr }}$ is the intake of ${ }^{13} \mathrm{C}$-enriched feed (in g); DL is the dietary (ADC) of macronutrients and stable carbon isotopes

(Mean values and standard deviations, $n 3$ ) lipid content (in \%); $\mathrm{ADC}_{\text {lipid }}$ is the $\mathrm{ADC}$ of dietary lipid (in \%); aDLR is the aDLR (in \%) obtained from the growth trial.

The recovery of carbon derived from dietary protein in whole-fish lipid (RPCL, \%) was calculated according to:

$$
\begin{aligned}
\mathrm{RPCL}= & \left(\mathrm{BM}_{\text {end }} \times \mathrm{BL}_{\mathrm{end}} \times C /\right. \text { wbl } \\
& \left.\times{ }^{13} \mathrm{CAPE}_{\mathrm{wbl}}\right) /\left(\mathrm{FI}_{\mathrm{enr}} \times C_{\text {diet }}\right. \\
& \left.\mathrm{APE}_{\text {diet }} \times \mathrm{ADC}_{\text {protein }}\right),
\end{aligned}
$$

where $C_{\text {diet }}$ is the diet carbon content (in \%); ${ }^{13} \mathrm{C} \mathrm{APE}_{\text {diet }}$ is the ${ }^{13} \mathrm{C}$ APE of the enriched diets (in \%); $\mathrm{ADC}_{\text {protein }}$ is the $\mathrm{ADC}$ of protein (in \%).

The $\mathrm{ADC}$ of nutrient $\mathrm{X}\left(\mathrm{ADC}_{(\mathrm{X})}\right)$ was calculated according to:

$$
\mathrm{ADC}_{(\mathrm{X})}=1-\left(\left(I_{\text {diet }} \times X_{\text {faeces }}\right) /\left(I_{\text {faeces }} \times X_{\text {diet }}\right)\right),
$$

where $I_{\text {diet }}$ and $I_{\text {faeces }}$ are yttrium concentrations recovered in the diet and faeces, respectively, and $X_{\text {faeces }}$ and $X_{\text {diet }}$ are the

\begin{tabular}{|c|c|c|c|c|c|c|c|c|c|c|c|c|}
\hline \multirow[b]{2}{*}{ Diets... } & \multirow[b]{2}{*}{ LPLE } & \multirow[b]{2}{*}{ LPME } & \multirow[b]{2}{*}{ LPHE } & \multirow[b]{2}{*}{ MPLE } & \multirow[b]{2}{*}{ MPME } & \multirow[b]{2}{*}{ MPHE } & \multirow[b]{2}{*}{ HPLE } & \multirow[b]{2}{*}{ HPME } & \multirow[b]{2}{*}{ HPHE } & \multicolumn{3}{|c|}{ Two-way ANOVA* } \\
\hline & & & & & & & & & & DP & $\mathrm{DE}$ & $\mathrm{DP} \times \mathrm{DE}$ \\
\hline \multicolumn{13}{|c|}{ SGR $(\% / d)$ and DEI (MJ) during the growth period } \\
\hline \multicolumn{13}{|c|}{ FCR $\dagger$} \\
\hline Mean & $1.48^{\mathrm{x}}$ & $1 \cdot 32^{y}$ & $1.27^{\mathrm{y}}$ & $1.42^{x}$ & $1.38^{x, y}$ & $1 \cdot 29^{y}$ & $1.38^{\mathrm{x}}$ & $1 \cdot 29^{x, y}$ & $1.24^{\mathrm{y}}$ & 0.052 & $<0.001$ & 0.338 \\
\hline SD & 0.03 & 0.06 & 0.05 & 0.03 & 0.02 & 0.09 & 0.07 & 0.03 & 0.05 & & & \\
\hline \multicolumn{13}{|l|}{ SGR } \\
\hline Mean & $0.96^{\mathrm{a}}$ & 1.02 & 1.02 & $1.01^{\mathrm{a}, \mathrm{b}}$ & 0.99 & 1.01 & $1.03^{b}$ & 1.05 & 1.04 & 0.028 & 0.336 & 0.266 \\
\hline SD & 0.01 & 0.04 & 0.04 & 0.01 & 0.01 & 0.06 & 0.04 & 0.01 & 0.03 & & & \\
\hline \multicolumn{13}{|l|}{ DEI§ } \\
\hline Mean & 83.5 & $86 \cdot 8$ & $82 \cdot 5$ & $85 \cdot 1$ & 83.7 & $85 \cdot 7$ & $87 \cdot 0$ & $87 \cdot 7$ & $87 \cdot 0$ & 0.027 & 0.584 & 0.218 \\
\hline SD & 2.9 & 1.4 & $1 \cdot 7$ & 1.5 & $2 \cdot 6$ & $2 \cdot 1$ & $2 \cdot 2$ & $2 \cdot 3$ & $2 \cdot 8$ & & & \\
\hline \multicolumn{13}{|c|}{ ADC of dietary macronutrients and stable carbon isotopes (\%) } \\
\hline \multicolumn{13}{|c|}{ Protein } \\
\hline Mean & $89 \cdot 2$ & $89 \cdot 0$ & $89 \cdot 1$ & 88.7 & $89 \cdot 8$ & $89 \cdot 3$ & 89.4 & 89.0 & $89 \cdot 1$ & 0.957 & 0.959 & 0.849 \\
\hline SD & $2 \cdot 2$ & $0 \cdot 8$ & $0 \cdot 8$ & 0.9 & $1 \cdot 6$ & $1 \cdot 1$ & 0.7 & 0.5 & $1 \cdot 0$ & & & \\
\hline \multicolumn{13}{|l|}{ Lipid } \\
\hline Mean & $95 \cdot 0$ & 94.6 & $94 \cdot 1$ & $95 \cdot 0$ & $95 \cdot 1$ & 94.5 & $95 \cdot 3$ & 94.9 & 94.9 & 0.605 & 0.482 & 0.969 \\
\hline SD & 1.6 & 0.5 & $1 \cdot 1$ & 0.6 & 0.4 & $1 \cdot 1$ & 1.8 & 0.7 & 0.7 & & & \\
\hline \multicolumn{13}{|l|}{ Starch } \\
\hline Mean & $94 \cdot 8$ & $95 \cdot 7$ & 94.8 & $95 \cdot 7$ & $95 \cdot 5$ & $94 \cdot 7$ & 95.2 & 95.5 & 94.6 & 0.933 & 0.307 & 0.924 \\
\hline $\begin{array}{l}\mathrm{SD} \\
{ }^{12} \mathrm{C}\end{array}$ & 1.4 & $1 \cdot 0$ & 0.2 & 0.8 & 0.7 & 0.9 & 1.3 & 1.9 & 1.5 & & & \\
\hline $\begin{array}{l}\text { Mean } \\
\text { SD } \\
{ }^{13} \mathrm{C}\end{array}$ & NA & NA & NA & NA & $\begin{array}{r}84.8 \\
0.8\end{array}$ & NA & NA & NA & NA & $0.668^{\|}$ & & \\
\hline Mean & NA & NA & NA & NA & $84 \cdot 3$ & NA & NA & NA & NA & & & \\
\hline SD & & & & & $1 \cdot 3$ & & & & & & & \\
\hline
\end{tabular}
concentrations of $X$ (protein, lipid, starch or carbon isotope) recovered in the faeces and diet, respectively ${ }^{(41)}$.

\section{Statistical analysis}

Data on FCR, SGR, ADC, DPR, aDLR, DER, DE intake, LDPO, RPCL, and the proximate composition of whole fish were subjected to two-way ANOVA to test for the main effects of,

Table 2. Feed conversion ratio (FCR), specific growth rate (SGR), digestible energy (DE) intake (DEI) and apparent nutrient digestibility coefficients

LPLE, low digestible protein (DP):Iow DE diet; LPME, low DP:medium DE diet; LPHE, low DP:high DE diet; MPLE, medium DP:Iow DE diet; MPME, medium DP:medium DE diet; MPHE, medium DP:high DE diet; HPLE, high DP:Iow DE diet; HPME, high DP:medium DE diet; HPHE, high DP:high DE diet; NA, not available.

a,b Mean values of DP within the DE groups were significantly different $(P<0.05$; Holm-Sidak method).

${ }^{x, y}$ Mean values of DE within the DP groups were significantly different $(P<0.05$; Holm-Sidak method).

* Two-way ANOVA $(\mathrm{df}=2,26)$ on the effects of DP, DE and their interaction $(\mathrm{DP} \times \mathrm{DE})$.

$\dagger F C R=$ feed consumed/biomass gain.

$\ddagger \mathrm{SGR}^{(51)}=\ln \left(\right.$ biomass $\left._{(\text {final }}\right) /$ biomass $\left._{\text {(initial) }}\right) /($ days in the trial) $) \times 100$.

$\S D E I=$ feed intake (growth trial) $\times \mathrm{DE}_{\text {diet }}$.

$\| P$ value is based on a $t$ test comparing the ADC of the two carbon isotopes. 
and interactions between, dietary DE and DP, respectively. Significant differences caused by a main effect were subsequently assessed using the Holm-Sidak all-pairwise multiple comparison test. A probability of $P<0.05$ was considered as significant in all analyses.

\section{Results}

\section{Diets and dietary ${ }^{13} \mathrm{C}$ enrichment}

The ingredient composition and chemical and isotopic analyses of the experimental diets are shown in Table 1 . The nine experimental diets were designed to comprise three different DP levels combined with three different DE levels in a $3 \times 3$ factorial design. The crude protein content of the LP, MP and HP diets ranged between 372-385, 404-409 and $443-453 \mathrm{~g} / \mathrm{kg}$ feed, respectively. Similarly, the DE levels ranged between $19 \cdot 6-19 \cdot 9,20 \cdot 6-21 \cdot 2$ and $21 \cdot 3-21 \cdot 6 \mathrm{MJ} / \mathrm{kg}$ feed for the LE, ME and HE diets, respectively. Collectively, the nine experimental diets covered a DP/DE range from 15.6 to $20.6 \mathrm{~g} / \mathrm{MJ}$. The dietary carbon content ranged between 46.2 and $51.3 \%$. The $\delta^{13} \mathrm{C}$ values of the non-enriched diets ranged between -22.5 and $-21.3 \%$, while the $\delta^{13} \mathrm{C}$ values of the enriched diets ranged between 593.9 and $754.5 \%$, cor- responding to the ${ }^{13} \mathrm{C}$ APE values from 0.673 to $0.846 \%$. The measured ${ }^{13} \mathrm{C}$ enrichment of dietary protein carbon ranged between 1.718 and $2.010 \%$. The indispensable amino acid (IAA) profile of the nine experimental diets is presented in Fig. 2. Also, the IAA profile of the Spirulina protein isolate employed and the IAA requirements of gilthead sea beam approximated by Kaushik ${ }^{(3)}$ are presented.

\section{Digestibility of macronutrients, energy and carbon isotopes}

The ADC of macronutrients and stable carbon isotopes are shown in Table 2 . The ADC of protein, lipid and starch ranged from 88.7 to $89 \cdot 8,94 \cdot 1$ to $95 \cdot 3 \%$ and 94.6 to $95 \cdot 7 \%$, respectively, and were not significantly affected by the dietary treatment. The ADC of the two stable carbon isotopes, ${ }^{12} \mathrm{C}$ and ${ }^{13} \mathrm{C}$, were $84 \cdot 8$ and $84.3 \%$, respectively. No significant differences between the ADC of the two carbon isotopes were observed.

\section{Feeding, growth, feed conversion ratio and mortality}

The results on SGR, FCR and total DE intake from the $89 \mathrm{~d}$ feeding trial are presented in Table 2. FCR (ranging from 1.24 to 1 48) were significantly lowered by increasing DE in

Table 3. Chemical and isotopic composition of whole fish

(Mean values and standard deviations, $n 3)^{*}$

\begin{tabular}{|c|c|c|c|c|c|c|c|c|c|c|c|c|c|}
\hline \multirow[b]{2}{*}{ Diets... } & \multirow[b]{2}{*}{ Initial } & \multirow[b]{2}{*}{ LPLE } & \multirow[b]{2}{*}{ LPME } & \multirow[b]{2}{*}{ LPHE } & \multirow[b]{2}{*}{ MPLE } & \multirow[b]{2}{*}{ MPME } & \multirow[b]{2}{*}{ MPHE } & \multirow[b]{2}{*}{ HPLE } & \multirow[b]{2}{*}{ HPME } & \multirow[b]{2}{*}{ HPHE } & \multicolumn{3}{|c|}{ Two-way ANOVA* } \\
\hline & & & & & & & & & & & DP & DE & $\mathrm{DP} \times \mathrm{DE}$ \\
\hline \multicolumn{14}{|c|}{ Proximate composition of fish (\%) } \\
\hline \multicolumn{14}{|c|}{ Protein } \\
\hline Mean & $17 \cdot 0$ & $17 \cdot 1$ & $16 \cdot 9$ & $16 \cdot 9$ & $17 \cdot 2$ & $17 \cdot 1$ & $17 \cdot 1$ & $17 \cdot 3$ & $17 \cdot 2$ & $17 \cdot 4$ & 0.015 & 0.176 & 0.826 \\
\hline SD & & $0 \cdot 1$ & $0 \cdot 1$ & $0 \cdot 1$ & 0.2 & 0.2 & 0.2 & 0.1 & 0.1 & 0.2 & & & \\
\hline \multicolumn{14}{|l|}{ Lipid } \\
\hline Mean & $16 \cdot 4$ & 21.5 & $22 \cdot 3$ & $22 \cdot 3$ & 21.9 & 21.5 & 21.9 & 21.9 & 21.4 & $20 \cdot 6$ & 0.273 & 0.508 & 0.657 \\
\hline SD & & 0.9 & 0.2 & 0.8 & $1 \cdot 3$ & 0.6 & 0.7 & 0.8 & 0.8 & 1.6 & & & \\
\hline \multicolumn{14}{|l|}{ Ash } \\
\hline Mean & 3.4 & 3.4 & 3.3 & 3.2 & 3.3 & 3.3 & 3.3 & 3.3 & $3 \cdot 3$ & $3 \cdot 2$ & 0.474 & 0.560 & 0.749 \\
\hline SD & & $0 \cdot 1$ & 0.2 & 0.1 & $0 \cdot 1$ & $0 \cdot 1$ & $0 \cdot 1$ & 0.0 & $0 \cdot 1$ & $0 \cdot 1$ & & & \\
\hline \multicolumn{14}{|l|}{ DM } \\
\hline Mean & $35 \cdot 6$ & $40 \cdot 8$ & 41.5 & 41.4 & $41 \cdot 0$ & $41 \cdot 0$ & $41 \cdot 1$ & $41 \cdot 2$ & $41 \cdot 1$ & $40 \cdot 0$ & 0.584 & 0.738 & 0.487 \\
\hline SD & & 0.4 & 0.7 & 0.5 & 0.8 & 0.5 & 0.8 & 0.7 & 0.6 & 1.0 & & & \\
\hline \multicolumn{14}{|c|}{ Carbon content of the whole-fish lipid fraction (\%) } \\
\hline \multicolumn{14}{|c|}{ Pre-enrichment } \\
\hline Mean & & $68 \cdot 30$ & $67 \cdot 42$ & 67.43 & 68.03 & $68 \cdot 11$ & 68.08 & 69.08 & $68 \cdot 50$ & $68 \cdot 33$ & 0.175 & 0.497 & 0.907 \\
\hline SD & & 0.75 & 0.44 & 0.25 & 0.93 & 1.63 & 0.89 & 0.83 & 1.08 & 1.44 & & & \\
\hline \multicolumn{14}{|c|}{ Post-enrichment } \\
\hline Mean & & $70 \cdot 01$ & $69 \cdot 86$ & 69.40 & 69.57 & $69 \cdot 32$ & $68 \cdot 55$ & 69.84 & $68 \cdot 70$ & $68 \cdot 32$ & 0.294 & 0.156 & 0.919 \\
\hline SD & & 0.14 & 0.29 & 0.21 & 0.11 & 0.06 & 0.34 & 1.04 & 0.61 & 0.25 & & & \\
\hline \multicolumn{14}{|c|}{$\delta{ }^{13} \mathrm{C}$ values of the whole-fish lipid fraction (\%०) } \\
\hline \multicolumn{14}{|c|}{ Pre-enrichment } \\
\hline Mean & & -23.75 & -23.50 & -23.33 & -23.80 & -23.57 & $-23 \cdot 34$ & -23.75 & -23.58 & $-23 \cdot 36$ & & & \\
\hline SD & & 0.03 & 0.06 & 0.06 & 0.01 & 0.06 & 0.02 & 0.05 & 0.05 & 0.04 & & & \\
\hline \multicolumn{14}{|c|}{ Post-enrichment } \\
\hline Mean & & -15.84 & $-15 \cdot 11$ & -15.05 & $-13 \cdot 17$ & -13.87 & -14.47 & -11.88 & -12.53 & -12.04 & & & \\
\hline SD & & 0.13 & 0.46 & 0.60 & 0.43 & 0.78 & 0.31 & 0.38 & 0.47 & 0.51 & & & \\
\hline \multicolumn{14}{|c|}{${ }^{13} \mathrm{C}$ atom per cent excess (APE) in the whole-fish lipid fraction ( $\left.\times 10^{-3} \%\right)$} \\
\hline Post-enri & Iment & & & & & & & & & & & & \\
\hline Mean & & 8.69 & $9 \cdot 23$ & $9 \cdot 10$ & 11.68 & $10 \cdot 67$ & $9 \cdot 75$ & 13.04 & $12 \cdot 15$ & 12.44 & & & \\
\hline SD & & $0 \cdot 11$ & 0.58 & 0.60 & 0.48 & 0.92 & 0.32 & 0.39 & 0.46 & 0.57 & & & \\
\hline
\end{tabular}

LPLE, low digestible protein (DP):low digestible energy (DE) diet; LPME, low DP:medium DE diet; LPHE, low DP:high DE diet; MPLE, medium DP:low DE diet; MPME, medium DP:medium DE diet; MPHE, medium DP:high DE diet; HPLE, high DP:Iow DE diet; HPME, high DP:medium DE diet; HPHE, high DP:high DE diet.

*Two-way ANOVA (df $=2,26)$ on the effects of DP, DE and their interaction (DP $\times$ DE). 
all the DP groups (LP, MP and HP), while no significant effects of DP were observed in FCR. SGR (ranging from 0.96 to $1.05 \% / \mathrm{d}$ ) were slightly, but significantly, higher with increasing DP in fish fed the LE diets, while no significant effects of DE on SGR were observed for any of the dietary treatment groups. DE intake ranged between 82.5 and $87.7 \mathrm{MJ}$, and was significantly different among the DP groups. No mortality occurred throughout the trial.

\section{Chemical composition of fish}

The chemical composition of whole fish at the beginning and at the end of the $89 \mathrm{~d}$ growth period is presented in Table 3. A two-way ANOVA showed no significant effects of dietary treatment on whole-body lipid, ash or DM, while the whole-body protein content was significantly higher in fish fed the HP diets than in fish fed the LP and MP diets. After $3 \mathrm{~d}$ of feeding using diets with a ${ }^{13} \mathrm{C}$-enriched protein content,

${ }^{13} \mathrm{C}$ APE in the lipid fraction of whole fish ranged between 8.69 and $13.04 \times 10^{-3} \%$ (Table 3).

\section{Nutrient retention efficiencies}

The results on DPR and aDLR based on the $89 \mathrm{~d}$ feeding trial are presented in Table 4 and Fig. 1(a) and (b). DPR ranged between 30.6 and $39 \cdot 2 \%$, and was significantly affected by both dietary DP and DE levels, showing increased retention efficiency with increasing DE and decreasing DP (Fig. 1(a)). aDLR ranged between 70.4 and $95 \cdot 1 \%$, and was also significantly affected by both dietary DP and DE levels, showing increased retention efficiency with increasing DP within the LE groups and/or with decreasing DE within the MP and HP groups (Fig. 1(b)). The results on DER are also presented in
Table 4 ranging between 48.0 and $54.9 \%$. DER was not significantly affected by the dietary treatment.

\section{Recovery of protein-derived carbon in fish lipid and contribution to the total lipid deposition of lipid synthesised from dietary protein de novo}

RPCL as determined from the stable isotope analyses ranged between 18.6 and $22.4 \%$, and was significantly affected by DE and the interaction between DP and DE. Pairwise comparisons showed that RPCL was significantly increased by increasing DP in the LE group and by decreasing DE in the MP group (Table 4; Fig. 1(c)). The contribution to the total lipid deposition of lipid synthesised from dietary protein de novo (LDPO) ranged between 21.6 and $30.2 \%$, and was significantly affected by both dietary DP and DE levels, showing increased contribution with decreasing DE and/or increasing DP (Table 4; Fig. 1(d)).

\section{Discussion}

The main purpose of the present study was to determine: (1) the magnitude of de novo lipogenesis originating from dietary protein in gilthead sea bream fed nine diets with different DP (330, 360 or $380 \mathrm{~g} / \mathrm{kg})$ and $\mathrm{DE}(20,21$ or $22 \mathrm{MJ} / \mathrm{kg}$ ) levels set up in a $3 \times 3$ factorial design, and (2) the overall contribution to lipid deposition from de novo lipogenesis originating from dietary protein in this species. Simple, high-quality raw material matrices were applied to assure the highest possible quality of dietary nutrients and to avoid possible anti-nutritional effects associated with certain plant raw materials ${ }^{(42)}$. $\mathrm{DP} / \mathrm{DE}$ levels of the nine experimental diets were deliberately formulated to also cover a lower range (from 15.6 to

Table 4. Digestible macronutrient retention and recovery of protein-derived carbon in the whole-fish lipid fraction

(Mean values and standard deviations, $n 3)^{\star}$

\begin{tabular}{|c|c|c|c|c|c|c|c|c|c|c|c|c|}
\hline \multirow[b]{2}{*}{ Diets... } & \multirow[b]{2}{*}{ LPLE } & \multirow[b]{2}{*}{ LPME } & \multirow[b]{2}{*}{ LPHE } & \multirow[b]{2}{*}{ MPLE } & \multirow[b]{2}{*}{ MPME } & \multirow[b]{2}{*}{ MPHE } & \multirow[b]{2}{*}{ HPLE } & \multirow[b]{2}{*}{ HPME } & \multirow[b]{2}{*}{ HPHE } & \multicolumn{3}{|c|}{ Two-way ANOVA* } \\
\hline & & & & & & & & & & DP & $\mathrm{DE}$ & $\mathrm{DP} \times \mathrm{DE}$ \\
\hline \multicolumn{13}{|c|}{ DPR (\%)† } \\
\hline Mean & $33 \cdot 2^{x}$ & $37 \cdot 3^{a, y}$ & $39 \cdot 2^{a, y}$ & $32 \cdot 1^{x}$ & $32 \cdot 6^{\mathrm{b}, \mathrm{x}}$ & $35 \cdot 4^{b, y}$ & $30 \cdot 6^{x}$ & $33 \cdot 0^{b, x}$ & $34.5^{\mathrm{b}, \mathrm{y}}$ & $<0.001$ & $<0.001$ & 0.237 \\
\hline SD & 0.8 & 1.5 & $1 \cdot 0$ & 1.0 & 0.7 & $2 \cdot 5$ & $2 \cdot 3$ & 0.3 & 0.5 & & & \\
\hline \multicolumn{13}{|c|}{ aDLR (\%)† } \\
\hline Mean & $79 \cdot 4^{\mathrm{a}}$ & 78.4 & $70 \cdot 4$ & $92 \cdot 2^{b, x}$ & $80 \cdot 5^{y}$ & $74 \cdot 7^{y}$ & $95 \cdot 1^{b, x}$ & $86 \cdot 3^{x, y}$ & $76 \cdot 0^{y}$ & 0.007 & $<0.001$ & 0.448 \\
\hline SD & 8.7 & $1 \cdot 7$ & 4.5 & $6 \cdot 0$ & $2 \cdot 2$ & $2 \cdot 1$ & $6 \cdot 4$ & $7 \cdot 2$ & 7.9 & & & \\
\hline \multicolumn{13}{|c|}{ DER $(\%) \dagger$} \\
\hline Mean & $48 \cdot 0$ & $51 \cdot 6$ & $52 \cdot 1$ & $52 \cdot 8$ & $51 \cdot 0$ & 53.4 & 53.2 & 54.9 & 53.0 & $0 \cdot 101$ & 0.524 & 0.405 \\
\hline SD & $3 \cdot 8$ & $1 \cdot 2$ & $2 \cdot 7$ & 3.0 & $1 \cdot 3$ & 1.9 & $3 \cdot 3$ & 3.4 & 3.9 & & & \\
\hline \multicolumn{13}{|c|}{ RPCL (\%) } \\
\hline Mean & $19 \cdot 2^{\mathrm{a}}$ & $19 \cdot 8$ & $19 \cdot 3$ & $22 \cdot 4^{\mathrm{b}, \mathrm{x}}$ & $18 \cdot 9^{y}$ & $18 \cdot 6^{y}$ & $21 \cdot 1^{b}$ & $19 \cdot 5$ & $19 \cdot 8$ & 0.243 & 0.001 & 0.005 \\
\hline SD & 0.9 & 0.7 & 0.3 & 0.9 & 0.9 & 0.2 & $1 \cdot 0$ & 0.8 & 1.5 & & & \\
\hline \multicolumn{13}{|c|}{ LDPO (\%) } \\
\hline Mean & $25 \cdot 9^{a, x}$ & $22 \cdot 1^{\mathrm{a}, \mathrm{y}}$ & $21 \cdot 9^{a, y}$ & $28 \cdot 8^{\mathrm{b}, \mathrm{x}}$ & $23 \cdot 4^{\mathrm{a}, \mathrm{b}, \mathrm{y}}$ & $21 \cdot 6^{a, z}$ & $30 \cdot 3^{b, x}$ & $25 \cdot 2^{b, y}$ & $26 \cdot 3^{b, y}$ & 0.002 & $<0.001$ & 0.542 \\
\hline SD & $2 \cdot 4$ & $1 \cdot 2$ & 0.9 & $2 \cdot 3$ & 1.9 & $1 \cdot 1$ & $2 \cdot 5$ & $2 \cdot 2$ & 2.5 & & & \\
\hline
\end{tabular}

LPLE, low digestible protein (DP):low DE diet; LPME, low DP:medium DE diet; LPHE, low DP:high DE diet; MPLE, medium DP:Iow DE diet; MPME, medium DP:medium DE diet; MPHE, medium DP:high DE diet; HPLE, high DP:Iow DE diet; HPME, high DP:medium DE diet; HPHE, high DP:high DE diet; DPR, digestible protein retention; aDLR, apparent digestible lipid retention; DER, digestible energy retention; RPCL, recovery of protein-derived carbon in fish lipid; LDPO, lipid deposition of protein origin.

${ }^{a, b}$ Mean values of DP within the DE groups were significantly different $(P<0.05$; Holm-Sidak method).

${ }^{x, y}$ Mean values of DE within the DP groups were significantly different $(P<0.05$; Holm-Sidak method).

* Two-way ANOVA $(\mathrm{df}=2,26)$ on the effects of DP, DE and their interaction $(\mathrm{DP} \times \mathrm{DE})$.

†DPR, aDLR and DER were calculated as the ratio between the amount of protein, lipid and energy retained by the fish and the amount of protein, lipid and energy digested by the fish during the growth trial, respectively. 

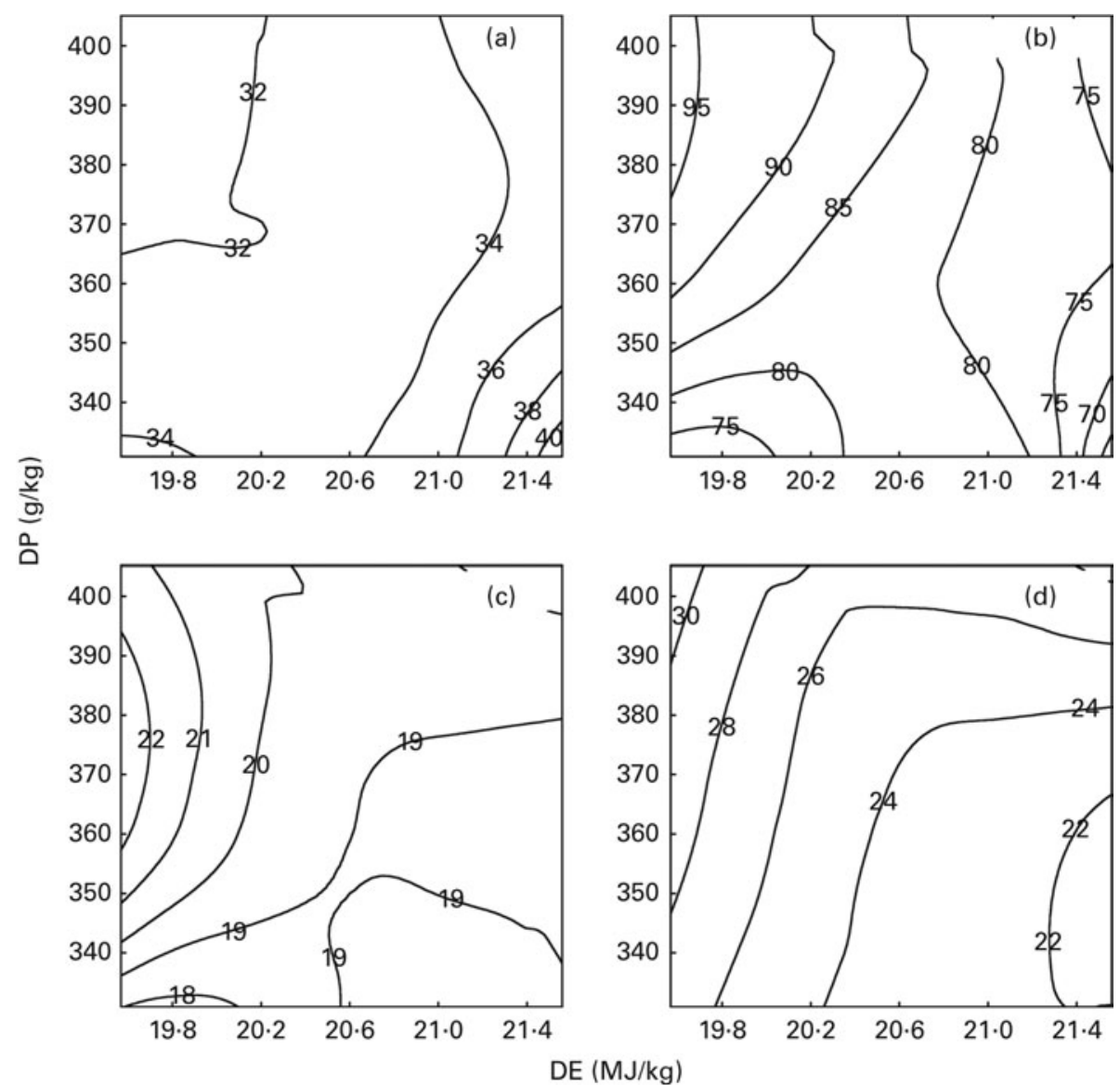

Fig. 1. Contour plots of the effects on (a) digestible protein (DP) retention (\%), (b) apparent digestible lipid retention (\%), (c) recovery of protein carbon in the lipid fraction of fish (\%) and (d) the percentage of total lipid deposit originating from dietary protein (\%) in fish fed the nine diets differing in DP content and digestible energy (DE) content for a period of 89 feeding days. The response values of changes in DE (horizontal axis) and DP (vertical axis) are given directly on the contour curves seen in the four plots. All diets were fed to triplicate tanks.

$20 \cdot 1 \mathrm{~g} / \mathrm{MJ})$ than previously recommended for gilthead sea bream by, for example, Lupatsch et al. ${ }^{(12)}$ (ranging from $19 \cdot 0$ to $22.6 \mathrm{~g} / \mathrm{MJ}$ for present fish size). This was done in order to incite the possible effects of protein deficiency on de novo lipogenesis, performance and nutrient retention efficiencies. Also, recommendations on dietary DE densities from the same authors were slightly more conservative (ranging between 15 and $20 \mathrm{MJ} / \mathrm{kg}$ ) than dietary DE densities of the present study (ranging between 19.6 and $21.6 \mathrm{MJ} / \mathrm{kg}$ ).

The dietary IAA profile of all the experimental diets satisfied the requirements put forward by Kaushik ${ }^{(3)}$. However, since these recommendations were expressed relatively to dietary $\mathrm{N}$ content, fish fed the low DP/DE diets might have experienced a general lack of DP.

The present study clearly demonstrated that DP, irrespective of the diet, did indeed contribute significantly to endogenous lipid biosynthesis in gilthead sea bream, as seen both from RPCL and from the contribution of lipid synthesised de novo to total lipid deposition (LDPO; Table 4; Fig. 1(c) and (d)). The results thereby corroborate the findings by Enes et $a l^{(30)}$ and Figueiredo-Silva et al. ${ }^{(27)}$ who both observed a significant correlation between hepatic lipogenic enzyme activity (glucose-6-phosphate dehydrogenase) and dietary protein level in diets for gilthead sea bream and blackspot seabream, respectively. These studies, including the present study, are thereby in contrast to the review by Tocher ${ }^{(43)}$, who claims that biosynthesis of fatty acids de novo is not likely to occur to any significant extent in marine predatory species. Also, using ${ }^{13} \mathrm{C}$-labelled dietary protein, Campbell ${ }^{(26)}$ found that between 9.7 and $44.5 \%$ of whole-body lipids in rainbow trout (Oncorbynchus mykiss) juveniles were derived from dietary protein, using diets with a protein:energy ratio ranging between 17.7 and $26.6 \mathrm{~g} / \mathrm{MJ}$, respectively. In the present study, approximately one-fifth (18.6-22.4\%) of the dietary DP supplied was converted into body lipid, irrespective of the dietary treatment. Fish fed the MPLE and HPLE diets displayed slightly higher RPCL values (22.4 and $21.1 \%$, respectively) than fish fed the remaining seven diets. This might have been due to these two diets having the highest DP/DE level in their respective DE groups, triggering excessive protein deamination and donation of extra carbon for lipid biosynthesis (Table 4; Fig. 1(c)). The contribution of lipid synthesised de novo from DP to total lipid deposition (LDPO) ranged between 21.6 and $30.2 \%$, confirming that de novo lipid synthesis from DP plays a major role in the overall lipid deposition in gilthead sea bream. LDPO was clearly elevated in the low-energy diets of each DP group, and by increasing 


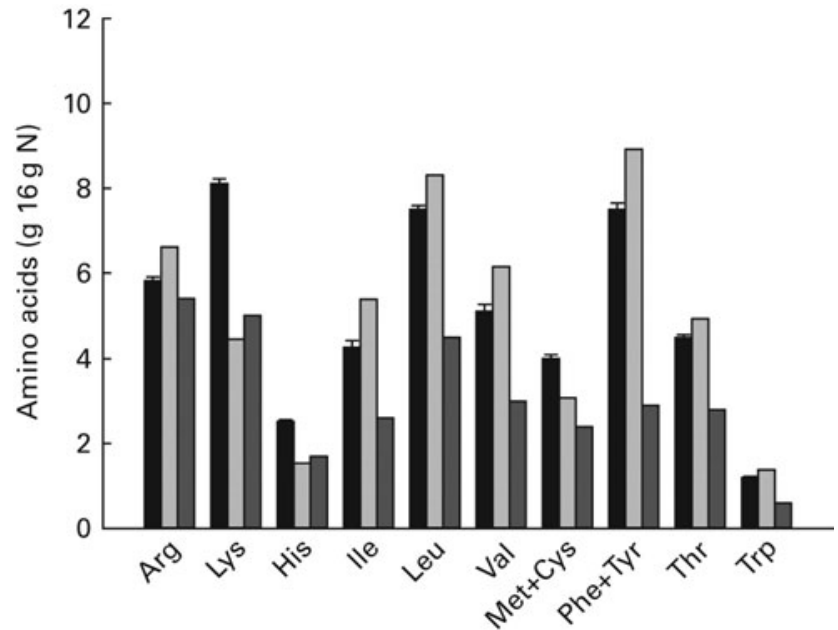

Fig. 2. Indispensable amino acid (IAA) profile including Cys and Tyr of the diets $(\square)$ and Spirulina protein isolate $(\square)$. The IAA requirements of gilthead sea bream (Sparus aurata) as approximated by Kaushik ${ }^{(3)}$ are shown as $\square$. Values are means $(n 9)$, with standard deviations represented by vertical bars.

DP generally (Table 4; Fig. 1(d)). Thus, LDPO values were directly related to dietary DP/DE levels. This was also reflected in the aDLR values that ranged between $70 \cdot 4$ and 95.1\% (Table 4; Fig. 1(b)). Hence, similar to the LDPO results, aDLR increased with increasing dietary DP and decreasing DE (i.e. increasing DP:DE ratio). Conversely, the DPR results showed increasing retention efficiencies with decreasing DP and/or increasing DE levels (i.e. decreasing DP:DE ratio). These results substantiate the so-called protein-sparing effect of substituting DE originating from DP with DE from non-protein sources, as already reported in a number of aquacultured species ${ }^{(23,44,45)}$, including gilthead sea bream ${ }^{(19,24,46)}$ (Table 4; Fig. 1(a)). Thus, the aDLR and DPR results combined suggest that while protein was spared by a decreasing dietary DP/DE level, the opposite was true for lipid, substantiating that deaminated DP was indeed converted into body lipids. The results of these opposing nutrient retention dynamics have supposedly rendered differences in the overall DER insignificant, as shown in Table 4. In addition, the proximate composition of whole fish was largely unaffected by the dietary treatment. No significant effects were observed in whole-body lipid, ash and DM, while a very small, but significant, effect of dietary DP was observed on whole-body protein content. This is in accordance with the finding of Bonaldo et al. ${ }^{(47)}$, who found no difference in the body composition of gilthead sea bream fed three diets differing in dietary DP:DE ratio for $81 \mathrm{~d}$. Thus, considering lipogenesis, nutrient retention and body composition results of the present study collectively, fish appeared to endeavour to rigorously maintain a certain whole-body energy status under a wide variety of dietary DP:DE ratios, even if substantial amounts of dietary protein were sacrificed to achieve this.

It was expected that the SGR values obtained from the growth period would not differ significantly among the dietary treatment groups, as fish were fed iso-DE throughout the trial. However, a small, but significant, difference was observed between the LPLE and HPLE fish. This could be partly explained by the slightly lower DE intake observed in fish fed the LPLE diet ( $83.5 \mathrm{MJ})$ compared with fish fed the HPLE diet $(87 \cdot 0 \mathrm{MJ})$, or by a possible general lack of DP experienced by LPLE fish. However, since dietary DP levels did not have any significant effect on the FCR obtained from the growth trial, the latter point probably does not apply. In contrast, FCR were clearly improved by a dietary DE increase. This clear link between dietary DE and FCR responses has been reported earlier in a number of aquacultured fish species ${ }^{(17,48)}$, including gilthead sea bream ${ }^{(12,13)}$ when growth was not limited by dietary protein content. The present results thereby indicate that gilthead sea bream have the ability to efficiently utilise diets with lower DP:DE ratios and higher energy densities (virtually resembling commercial diets for salmonid species) than previously recommended ${ }^{(12)}$ without showing adverse effects on the proximate composition or performance of the fish.

The measured ADC of protein, lipid and starch did not differ significantly among the dietary treatments, which was also expected from diet optimisation, considering that the same raw materials were used in all diets, and only inclusion levels differed.

An inherent problem by using a tracer to investigate metabolic pathways is the potential difference in functional behaviour between the tracer and the tracee. In the present study, a uniformly ${ }^{13} \mathrm{C}$-labelled Spirulina protein isolate was used to trace the fate of dietary protein, which mainly originated from con-kix fishmeal. However, possible differences in overall protein digestibility, amino acid profile and individual amino acid digestibility between the Spirulina protein isolate and dietary protein could potentially lead to differences in the way that the tracer and the tracee were metabolised, rendering the tracer unsuitable for the purpose. However, when comparing the IAA profile of the Spirulina protein isolate and experimental diets, only small differences were apparent (Fig. 2). The only clear difference was a considerably higher lysine content of the experimental diets. This difference, however, was unlikely to change the overall pattern in amino acid deamination since the remaining amino acids were basically in balance, and all experimental diets, as such, fulfilled the general IAA requirements of gilthead sea bream $^{(3,4)}$. The ADC of individual amino acids were not determined in the present trial. However, the ADC of measured stable carbon isotopes displayed no significant differences between ${ }^{12} \mathrm{C}$ and ${ }^{13} \mathrm{C}$, indicating that Spirulina whole protein was indeed digested similarly to the remaining dietary protein fraction. Thus, it was assumed that the Spirulina protein isolate could be considered a true tracer, not behaving functionally different from the tracee.

\section{Conclusion}

For the first time, orally administered ${ }^{13} \mathrm{C}$-labelled protein was applied to quantify de novo lipogenesis originating from dietary protein, and to determine the importance of this in the overall body lipid deposition in gilthead sea bream. Irrespective of the dietary treatment, the fish converted substantial 
amounts of carbon derived from dietary protein into body lipids, which in turn contributed significantly to total body lipid deposition. Despite dietary effects on protein and lipid retention efficiencies and de novo lipogenesis, the fish were able to maintain a constant retention of DE with no significant effects seen on the whole body composition. The results indicate that this species may have evolved to maximise energy storage (in the form of lipid) for seasonal, migratory or maturation purposes at the expense of increasing body size through more efficient use of protein for growth. Additionally, the improvement of FCR by increased DE combined with an improvement of DPR with decreasing DP/DE levels suggest that gilthead sea bream is able to efficiently utilise feeds within a wide range of dietary DP:DE ratios, which could be taken into consideration in the future production of commercial feeds for this species.

\section{Acknowledgements}

The authors would like to thank the technical and laboratory staff at DTU Aqua, Hirtshals, Denmark, BioMar A/S's trial station, Hirtshals, Denmark and Ris $\varnothing$ DTU, Roskilde, Denmark for their invaluable help during the experimentation and analytical work. The present study was part of K. S. E.'s PhD study, sponsored by DTU Aqua and BioMar A/S, Denmark. The authors' responsibilities were as follows: all authors helped to plan the research; K. S. E. was responsible for the biological trials; K. S. E. performed the laboratory work; K. S. E. analysed the data; all authors helped to interpret the results; K. S. E. wrote the manuscript; all authors helped to proofread the manuscript. There are no conflicts of interest to report.

\section{References}

1. Wilson RP (1994) Utilization of dietary carbohydrate by fish. Aquaculture 124, 67-80.

2. Akiyama T, Oohara I \& Yamamoto T (1997) Comparison of essential amino acid requirements with $\mathrm{A} / \mathrm{E}$ ratio among fish species. Fish Sci 63, 963-970.

3. Kaushik S (1998) Whole body amino acid composition of European seabass (Dicentrarchus labrax), gilthead seabream (Sparus aurata) and turbot (Psetta maxima) with an estimation of their IAA requirement profiles. Aquat Living Resour 11, 355-358.

4. Peres H \& Oliva-Teles A (2009) The optimum dietary essential amino acid profile for gilthead seabream (Sparus aurata) juveniles. Aquaculture 296, 81-86.

5. Wilson RP (2002) Amino acids and proteins. In Fish Nutrition, pp. 143-179 [JE Halver and RW Hardy, editors]. San Diego, CA: Academic Press.

6. Cowey C (1994) Amino acid requirements of fish - a critical appraisal of present values. Aquaculture 124, 1-11.

7. Cowey C (1995) Protein and amino acid requirements: a critique of methods. J Appl Ichthyol 11, 199-204.

8. Cho C (1992) Feeding systems for rainbow trout and other salmonids with reference to current estimates of energy and protein requirements. Aquaculture 100, 107-123.

9. Bowen S (1987) Dietary protein requirements of fishes - a reassessment. Can J Fish Aquat Sci 44, 1995-2001.

10. Cowey C (1995) Intermediary metabolism in fish with reference to output of end products of nitrogen and phosphorus. Water Sci Technol 31, 21-28.
11. Watanabe T (2002) Strategies for further development of aquatic feeds. Fisheries Sci 68 , 242-252.

12. Lupatsch I, Kissil GW \& Sklan D (2003) Defining energy and protein requirements of gilthead seabream (Sparus aurata) to optimize feeds and feeding regimes. Isr J AquacultBamid 55, 243-257.

13. Lupatsch I, Kissil G, Sklan D, et al. (2001) Effects of varying dietary protein and energy supply on growth, body composition and protein utilization in gilthead seabream (Sparus aurata L.). Aquacult Nutr 7, 71-80.

14. Beamish F \& Medland T (1986) Protein sparing effects in large rainbow trout, Salmo gairdneri. Aquaculture $\mathbf{5 5}$, $35-42$.

15. Einen O \& Roem AJ (1997) Dietary protein/energy ratios for Atlantic salmon in relation to fish size: growth, feed utilization and slaughter quality. Aquacult Nutr 3, 115-126.

16. Kaushik S \& Médale F (1994) Energy requirements, utilization and dietary supply to salmonids. Aquaculture 124, $81-97$.

17. Hillestad M \& Johnsen F (1994) High energy low protein diets for Atlantic salmon - effects on growth, nutrient retention and slaughter quality. Aquaculture 124, 109-116.

18. Grisdale-Helland B \& Helland SJ (1997) Replacement of protein by fat and carbohydrate in diets for Atlantic salmon (Salmo salar) at the end of the freshwater stage. Aquaculture 152, 167-180.

19. Company R, Calduch-Giner JA, Pérez-Sánchez J, et al. (1999) Protein sparing effect of dietary lipids in common dentex (Dentex dentex): a comparative study with sea bream (Sparus aurata) and sea bass (Dicentrarchus labrax). Aquat Living Resour 12, 23-30.

20. Hemre GI \& Sandnes K (1999) Effect of dietary lipid level on muscle composition in Atlantic salmon Salmo salar. Aquacult Nutr 5, 9-16.

21. Kaushik SJ \& Oliva-Teles A (1985) Effect of digestible energy on nitrogen and energy balance in rainbow trout. Aquaculture 50, 89-101.

22. Dias J, Alvarez MJ, Diez A, et al. (1998) Regulation of hepatic lipogenesis by dietary protein/energy in juvenile European seabass (Dicentrarchus labrax). Aquaculture 161, 169-186.

23. Venou B, Alexis MN, Fountoulaki E, et al. (2003) Effect of extrusion of wheat and corn on gilthead sea bream (Sparus aurata) growth, nutrient utilization efficiency, rates of gastric evacuation and digestive enzyme activities. Aquaculture 225, 207-223

24. Fernández F, Miquel AG, Córdoba M, et al. (2007) Effects of diets with distinct protein-to-carbohydrate ratios on nutrient digestibility, growth performance, body composition and liver intermediary enzyme activities in gilthead sea bream (Sparus aurata, L.) fingerlings. J Exp Mar Biol Ecol 343, $1-10$.

25. Ekmann KS, Dalsgaard J, Holm J, et al. (2013) Glycogenesis and de novo lipid synthesis from dietary starch in juvenile gilthead sea bream (Sparus aurata) quantified with stable isotopes. BrJ Nutr 109, 2135-2146.

26. Campbell PJ (1999) Food consumption, growth and amino acid metabolism in rainbow trout (Oncorbynchus mykiss). Application of ${ }^{15} \mathrm{~N}$ and ${ }^{13} \mathrm{C}$ stable isotope tracers. PhD dissertation, University of Dundee, pp. 1-191.

27. Figueiredo-Silva AC, Corraze G, Rema P, et al. (2009) Blackspot seabream (Pagellus bogaraveo) lipogenic and glycolytic pathways appear to be more related to dietary protein level than dietary starch type. Aquaculture 291, 101-110.

28. Sargent JR, Henderson RJ \& Tocher DR (1989) The lipids. In Fish Nutrition, pp. 153-218 [JE Halver, editor]. New York: Academic Press. 
29. Enes P, Panserat S, Kaushik S, et al. (2006) Effect of normal and waxy maize starch on growth, food utilization and hepatic glucose metabolism in European sea bass (Dicentrarchus labrax) juveniles. Comp Biochem Phys A 143, 89-96.

30. Enes P, Panserat S, Kaushik S, et al. (2008) Growth performance and metabolic utilization of diets with native and waxy maize starch by gilthead sea bream (Sparus aurata) juveniles. Aquaculture 274, 101-108.

31. European Commission (1986) Council Directive of 24 November 1986 on the approximation of laws, regulations and administrative provisions of the Member States regarding the protection of animals used for experimented and other scientific purposes (86/609/EEC). http://ec.europa.eu/food/ fs/aw/aw_legislation/scientific/86-609-eec_en.pdf (accessed October 2012).

32. ISO (2005) Animal Feeding Stuffs - Determination of Nitrogen Content and Calculation of Crude Protein Content - Part 2: Block Digestion/Steam Distillation Method No. ISO 5983-2:2005. Geneva: ISO.

33. Bligh EG \& Dyer WJ (1959) A rapid method of total lipid extraction and purification. Can J Biochem Physiol 37, 911-917.

34. Kolar K (1992) Gravimetric determination of moisture and ash in meat and meat products - NMKL Interlaboratory Study. J AOAC Int 75, 1016-1022.

35. ISO (1998) Water Quality - Determination of 33 Elements by Inductively Coupled Plasma Atomic Emission Spectroscopy No. ISO 11885. Geneva: ISO.

36. DS (Danish Standards) (2002) Foodstuffs - Determination of Trace Elements - Pressure Digestion No. DS/EN 13805:2002. Charlottenlund: DS.

37. Knudsen K (1997) Carbohydrate and lignin contents of plant materials used in animal feeding. Anim Feed Sci Technol 67, 319-338.

38. European Commission (2009) Commission Regulation (EC) no. 152/2009 of 27 January 2009 Laying Down the Methods of Sampling and Analysis for the Official Control of Feed (Text with EEA Relevance).
39. ISO (2005) ISO 13904:2005 Animal Feeding Stuffs - Determination of Tryptophan Content. Geneva: ISO.

40. Craig H (1957) Isotopic standards for carbon and oxygen and correction factors for mass spectrometric analysis of carbon dioxide. Geochim Cosmochim Acta 12, 133-149.

41. Maynard LA \& Loosli JK (1969) Animal Nutrition, 6th ed. New York: McGraw-Hill Book Company.

42. Gatlin DMIII, Barrows FT, Brown P, et al. (2007) Expanding the utilization of sustainable plant products in aquafeeds: a review. Aquacult Res 38, 551-579.

43. Tocher D (2003) Metabolism and functions of lipids and fatty acids in teleost fish. Rev Fish Sci 11, 107-184.

44. Dias J, Corraze G, Arzel J, et al. (1999) Nutritional control of lipid deposition in rainbow trout and European seabass: effect of dietary protein/energy ratio. Cybium 23, 127-137.

45. Hemre GI, Mommsen TP \& Krogdahl A (2002) Carbohydrates in fish nutrition: effects on growth, glucose metabolism and hepatic enzymes. Aquacult Nutr 8, 175-194.

46. Vergara J, Robainà L, Izquierdo M, et al. (1996) Protein sparing effect of lipids in diets for fingerlings of gilthead sea bream. Fish Sci 62, 844-844.

47. Bonaldo A, Isani G, Fontanillas R, et al. (2010) Growth and feed utilization of gilthead sea bream (Sparus aurata, L.) fed to satiation and restrictively at increasing dietary energy levels. Aquacult Int 18, 909-919.

48. El-Mowafi A, Ruohonen K, Hevroy EM, et al. (2010) Impact of digestible energy levels at three different dietary amino acid levels on growth performance and protein accretion in Atlantic salmon. Aquacult Res 41, 373-384.

49. Subcommittee on Fish Nutrition, National Research Council (1993) Nutrient Requirements of Fish, pp. 16-33. Washington, DC: National Academy Press.

50. Blaxter K (1989) Energy Metabolism in Animals and Man, pp. 23-38. Cambridge: Cambridge University Press.

51. Hopkins KD (1992) Reporting fish growth: a review of the basics. J World Aquac Soc 23, 173-179. 